\title{
THE EFFECT OF NATIONAL BRAND IN ATTRACTING TOURISTS IN TOURISM INDUSTRY
}

\author{
Mohseninia, $\mathrm{I}^{1}$ and Lotfi, $\mathrm{H}^{2}$ \\ ${ }^{1,2}$ Islamic Azad University, Garmsar Branch, Iran
}

\begin{abstract}
After the Islamic Revolution, Iran got the $48^{\text {th }}$ place in the list of attracting the foreign tourists, in 2013 by having 4 million and 700 thousands foreign tourist (UNWTO, 2013). Having no brand in tourism has been always an apprehension of authorities and activists of this industry, so with no excitement and by having a systematic and scientific approach, the present study assessed the role of factors such as top quality, better service and more attraction in management of tourism brand, through surveying the main three elements of management of tourism brand which are "brand identity, brand mentality and brand positioning; the goal of this study was compilation of tourism marketing strategies. To realize this, the researcher used "foreign tourists which visit ancient and popular sites" as the statistical population and "convenience sampling" as the method of research. Friedman tests, factor analysis and regression were used for studying the differences, ranking the factors and surveying the amount of each factor's effect on Iran's tourism industry. The result of this research showed that the factor of tourists' perception, cognition and attitude toward the destination was the most important factor on attracting tourists through national tourism brand.
\end{abstract}

Keywords: tourism brand, brand identity, brand mentality, brand positioning, Iran.

\section{INTRODUCTION}

The growth and development of one of the profitable industries (tourism) is linked to the development of today's world to the extent that many investors and economists are surprised of the capabilities of this industry and its impact on the trend of the global village. Therefore, many countries are trying their best to promote the position of their tourism industry. In this regard and for the prosperity of this young industry, incentive policies for tourists have been arranged such as shopping festivals, tourist tax refund or tax-free law and this way a good infrastructure has been made to attract maximum tourists (Yazdi, 1389,137). But after a while, another matter was emerged among tourism officials in most countries: after the expansion of infrastructure and attracting the passengers, how can we keep the country alive in their mind and make loyal passengers to the country's tourism facilities and expect a continuous flow of tourists into the borders?
According to experts, one way to achieve this goal is to produce a national brand for its tourism industry. Statistics show that, in the last hundred years Iran's total oil revenues is about 16 thousand billion, but America could earn this amount through tourism industry in 10 years! France hosts 74 million tourists annually; this means that a figure equivalent to Iran's population go to Paris every year to see Eiffel Tower, the Louvre and Champs Elysees, while Iran's share in global tourism market is hardly $0.04 \%$, and at the best it hosts only 2 million tourism per year (Moazzez, 1392, 130). Turkey, Iran's neighbor, earns 20 billion \$ and Egypt earns 15 billion \$ per year through tourism industry; also UAE earns 14 million dollars per year through attracting foreign tourists from different countries who travel to this small country in the southern coast of Persian gulf (balouiee, 1391:26). Being a Muslim and developing country, Malaysia can be compared to Iran. Although it is not as vast as Iran and has less tourist attractions compared to Iran, it earns 15-20 million dollars per year through tourism industry. According to the statics presented by the World Economic Forum, 
among world's 139 countries, Turkey ranked $50^{\text {th }}$ in the region of central Asia, which is the highest grade, while Iran ranked $114^{\text {th }}$ which is one of the lowest grades. Iran's position will be further clarified with respect to other neighboring countries such as Georgia and Azerbaijan which ranked respectively 73, 83 and Armenia which ranked 90 with a degree of increase (soleimani 1391, 32). So the last action that has been taken by Cultural Heritage Organization of Iran to improve the situation of Iran in tourism industry, is to establish group work on producing tourism brand for the country. Although this is not a new subject in the tourism industry of the world or Iran, it was the main reason of doing the present research. Iran's map is called "CAT" and Persian cat is famous in the world; so is it possible to make a tourism bran using this point? Meanwhile, Homa has been known as a brand on Iran Airline (Homa ${ }^{i}$ ), so can we assign this symbol as the country's tourism brand?

Brand in tourism industry is defined by experts as: brand is a sentence, slogan, logo, Music or part of a film according to a particular country's tourism potentials that always remain in the minds of consumers as tourists. Branding or building up a reputation is an effective strategy in attracting customers and successful sale which leads to customer loyalty. Brand is effectively applied in tourism industry and companies which provide tourism services, compete using brand making strategies in tourism industry. Here it is necessary to introduce three main elements in tourism brand management. These elements are: brand identity, brand image and brand positioning (Barezani 1392, 66). Aaker (1991), believes that brand means: discerning goods or services of one seller or group of sellers and to differentiate these goods and services from their competitors' products. Ritchie and Ritchie (1998), define destination brand as a name, symbol, logo, trademark or any other graphic which both defines and differentiates the destination, and also promises a memorable trip (which is exclusively due to the characteristics of the destination) to the tourists. Also it integrates and consolidates good memories of the tourists from destination and makes it richer. Destination brand means the situation of a place which makes it attractive to visit, and according to Baker (2012) it is sometimes referred to as tourism brand. Many cities and places are more willing to tourism brand or destination brand compared to umbrella brand, because it is more effective and is more organized in declaring the properties of a special place. Morgan, Pritchard and Pride (2004) state that making a destination brand is the creation of an image or reputation which attracts investors or tourists to the destination. Kaplanidou, \& Vogt (2003) state: destination brand creates an image from destination in customers' minds and is the tourist's main element and criteria for decision making. Therefore creating a strong brand for destination is a mechanism for attracting more tourists. Many researchers, including Hankinson (2004) and Deslandes (2003) and Ritchie, Blaine, and Levy (2005) believe that, there have not been many studies conducted about destination brand and this concept has not been used much in the field of tourism. So in the present study, referring to Iran's tourist trustee organizations, the researcher has tried to discover the status of tourist brand and branding activities in Iran (Hezarjaribi, 1391: 137).

\section{LITERATURE REVIEW}

As a theoretical background we can name works such as: brand architecture (cleverdon and Fabricius, 2006), elements of the brand (ETC, 2010), country branding (florek, 2005, Morgan et al., 2003, 2002), the Tourist gaze (Urry, 1990), tourist destinations branding model (saarinen, 1997, Iliachenko, 2005, ooi, 2001), A model of destination image formation (Baloglu and Mcclear, 1999), brand building matrix (Nworah, 2005: 3, and Olins, 2002: 244), the pyramid brand model (cleverdon and Fabricius, 2006: 9, Kaplanidou and Vogt, 2003: 2), Tourist characteristics and the perceived image of tourist destination (beerli and Martin, 2004), the hexagonal country branding (Anholt, 2005), 5 phase branding (Heath, 2007), Customer based brand equity for a destination (koneenik and Gartner, 2007), Destination identity elements model (Ahonen, Saraniemi and Tahtinen, 2007), decision making process on selecting destination model (Butler, McCartney, and Bennett, 2009), the brand equity model by Kim and colleagues (Kim et al., 2009), two-dimensional brand and destination image model (Saraniemi, 2009), destination image model in supply and demand domain (Saraniemi, 2009), the pattern of brand assets model (ETC / UNWTO, 2010), the brand cycle model 
(ETC / UNWTO, 2010 ), the Qu et al. model (Qu et al., 2011), the Garcia et al. model, Gomez and Molina model,(2012), DMOs success factors (Bornhorst et al., 2010), branding and power (Prideaux and Cooper, 2002). As a background and executive experience we can name countries such as Turkey, Australia, India, Malaysia, Thailand, China and Bangladesh which have created brand in tourism industry. Spending million dollars for creating a brand by these countries illustrates the importance of the issue. For example Thailand has been able to use the brand of "Land of Smiles" and introduce it as a symbol in the minds of tourists. Australia is another example which is famous for its slogan: Land of kangaroos! Today, all of these brands are well-known in the minds of active or inactive tourists. Turkey, as Iran's neighbor, which has the strongest and most successful tourist attraction system in the region has spent about 40 million euros for creating brand or national brand.

\section{The importance of branding for destination}

Murphy and others (2007) state that tourism brand of a destination, gives information to the visitor to know and identify the destination, differentiate it from its competitors and make some expectations about the trip before he/she start it. Ritchie and Ritchie (1998) believe that even the information after travel are affected by destination brand. Clark (2000) cites six advantages in tourism branding: 1.branding helps to reduce the choice; 2 branding helps in reducing the impact of intangibility (because knowing the physical properties of the destination brand and its symbolic concept deactivates intangibility); 3. Branding conveys consistency across multiple outlets and ensures that tourists' expectations about destination will be fulfilled; 4. Branding can reduce operational risk, social risk, economic risk and psychological risk; 5. Branding facilitates precise segmentation; 6 . Branding helps to provide a focus for the integration of producer effort, helping people to work towards the same outcome. Countries often have the same reasons for branding. The most important reason is to differentiate the destination and making a special position for it in order to encourage tourists to expend more, and raise the living standards of the residents. According to Park and Patrick (2006), economic well-being of residents by the help of tourism development, destination image management and tourist attraction is possible only by creating a favorable image. Blaine et al. (2005) state that brand of a country highly influences on tourist decision when choosing a destination. Gras (2008) says that the achievement of this goal is possible only by applying the concepts of branding and trying to create a positive image in the minds of the present and future visitors; this way they may travel to a specific destination among numerous competitors (Barezani 1392:76).

\section{Conceptual Framework of the Research}

The model used in this research is close to Hankinson's model because it contains more considerations and is easy to understand. There is a plan in this model or brand framework for developing the brand and instilling it to the target group which may be listed in the prospects of the trustee organization. This kernel has three components:

1. Brand Identity; which consists of three components: (a) functional attributes or tangible elements of the brand which contain business and tourism activities (e.g., restaurants, hotels, recreational activities and facilities, museums, etc.).

(B) Symbolic characteristics or intangible elements that ascertain the need for social approval, self-esteem and self-expression. Characteristics of the visitors, type and quality of services and behavior of service staff are some examples for this case. (C) experimental features that are the result of the merger of two previous features; this component is more general and explains the real feelings of experiencing the place, such as relaxation, excitement, happiness, ... and clarifies the overall atmosphere or created character of the place for the visitor.

2. Brand positioning which reflects position of the brand according to the competitive context, in the sense that it shows similarities and differences with its competitors. Similarities like a national monument or mosque in several destinations, and differences like a certain feature that may be in a mosque in a particular destination.

3. Brand image and genuineness which means the loyalty to the brand promises 
and commitments. Brand personality or whatever related to the destination brand must be real and should have a logical support. Innovative branding needs accurate marketing and smart investments in facilities and services. Without investment and developing services and unique features, the core of brand will not be strengthened and brand loyalty and frequent purchase will not be achieved (Moazzez, 1392: 135).

\section{RESEARCH METHODOLOGY}

The variables of this study are divided into two main categories based on selected conceptual model: a) independent variables which are determined based on three basic elements of the model (i.e., understanding, knowledge and attitudes), and b) dependent variable which is the central factor of the model (brand). Each one of the dependent and independent variables have some components and sub-categories. In general, independent variables have 9 sub-categories and dependent variable has three sub-categories. Each of the 9 sub-categories of the independent variables has been compared to one of the three sub-categories of the dependent variable. The assessment basis of the impact of independent variables on the dependent variables, is based on population responses and will be tested by ANOVA model and regression analysis. Among 150 experts of the tourism trustee organization (Cultural Heritage, Handicrafts and Tourism) by referring to the chart and using a Likert 5 option (1-strongly disagree and 5 strongly agree), the opinions of 113 people are collected about whether the independent variables, reinforce the dependent variable or not. To check the reliability of data collection tool (questionnaire) with pre-test and Cronbach's alpha has been done. The alpha value (everywhere) is more than minimum acceptable value (0.7) and no restriction on the use of written questionnaires was observed. At the beginning of the questionnaire demographic information such as age, gender, experience in the field of tourism and education, is questioned; so it is determined that the sample contain 56 percent women and 44 percent male (this reflects the relative balance of the sample), and more than 76 percent of the sample have over 5 years of work experience and $46 \%$ have over 10 years of work experience in tourism. This confirms the ability to cite and authenticate respond and comment on the investigation subject. $64 \%$ of respondents have B.A and lower and 31 percent have masters and $5 \%$ have $\mathrm{Ph}$.D. In addition, about $71 \%$ of the population are under 40 years, which indicates the relative youth of the respondents.

\section{ANALYSIS OF RESULTS}

Table number 1 shows the results of factor analysis that is somehow a factor authentication of the variables used in this research; Cronbach's alpha coefficient is shown in the table as well. It should be noted that the items which had low factor loading and their presence did not help to explain variance, were excluded. So the items reported in the table below, are not all the items mentioned in the final research questionnaire. Finally, after factor authentication, Cronbach's alpha coefficient was reported to confirm internal and final consistency of the items. Kayser Meyer Olkin measure of sampling adequacy (KMO) was fluctuating between $62 \%-81 \%$, which indicates the suitability of data for factor analysis.

Table 1: Exploratory factor analysis variables and their reliability

\begin{tabular}{llll}
\hline $\begin{array}{l}\text { Cronbach } \\
\begin{array}{l}\text { Alpha } \\
\text { coefficient }\end{array}\end{array}$ & $\begin{array}{l}\text { Defined } \\
\text { variance } \\
\text { percentage }\end{array}$ & $\begin{array}{c}\text { Kmo } \\
\text { (index) }\end{array}$ & variables \\
\hline 0.81 & 0.42 & 0.81 & attitude \\
0.79 & 0.71 & 0.78 & understanding \\
0.77 & 0.71 & 0.62 & Knowledge \\
\hline
\end{tabular}

Source: calculations of the present study, 1394

According to the tourists' descriptive statistics of the dependent and independent variables of the research, as it is clear in the table 1 , the average of the all variables is more than the mean. Meanwhile, "knowledge about destination" and "understanding about the other variables" (as two variables) had lower mean. According to size and condition of the sample, Friedman test and regression were used to evaluate the effect of national brand in attracting tourists to Iran. Given that all variables are normally distributed (according to Kolmogorov test - onesample Smirnov -Table 2), this test can be used to check the research. 
Table 2 : Kolmogorov test - one-sample Smirnov (dependent variable: brand identity, brand positioning and brand image)

\begin{tabular}{|c|c|c|c|}
\hline knowledge & attitude & understanding & Z-statistic and significant coefficients \\
\hline $1 / 076$ & $0 / 894$ & $0 / 732$ & Kolmogorov - Smirnov z-statics for brand identity and character \\
\hline $0 / 117$ & $0 / 141$ & $0 / 223$ & Significant coefficients for brand identity and character \\
\hline $0 / 564$ & $1 / 124$ & $0 / 830$ & Kolmogorov-Smirnov z-statistic for brand positioning \\
\hline $0 / 315$ & $0 / 092$ & $0 / 212$ & Significant coefficients for brand positioning \\
\hline $1 / 261$ & $1 / 276$ & $0 / 836$ & Kolmogorov-Smirnov z statistic for brand image \\
\hline $0 / 083$ & $0 / 077$ & $0 / 202$ & Significant coefficients for brand image \\
\hline
\end{tabular}


Table 3: mean test results of a society

\begin{tabular}{|c|c|c|c|c|c|c|c|c|}
\hline Test result & Maximum & minimum & t-statics & $\begin{array}{l}\text { Sample } \\
\text { numbers }\end{array}$ & $\begin{array}{l}\text { Average } \\
\text { standard } \\
\text { deviation }\end{array}$ & $\begin{array}{l}\text { Score } \\
\text { mean }\end{array}$ & $\begin{array}{l}\text { Dependent } \\
\text { variables }\end{array}$ & $\begin{array}{l}\text { Independent } \\
\text { variables }\end{array}$ \\
\hline $\begin{array}{l}\text { Tourists' understanding from Iran } \\
\text { hasn't led to strengthen tourism } \\
\text { brand identity and character. }\end{array}$ & $-0 / 91$ & $-1 / 16$ & -16.49 & 113 & .06301 & $1 / 96$ & $\begin{array}{l}\text { Brand } \\
\text { identity and } \\
\text { character }\end{array}$ & \\
\hline $\begin{array}{l}\text { Understanding of tourists from Iran } \\
\text { hasn't led to Iran's ascendency in } \\
\text { compare to its competitors. }\end{array}$ & $-0 / 93$ & $-1 / 17$ & -17.30 & 113 & .06105 & $1 / 94$ & $\begin{array}{l}\text { Brand } \\
\text { positioning }\end{array}$ & \\
\hline $\begin{array}{l}\text { Understanding of tourists has not } \\
\text { led to maintenance of Iran's brand } \\
\text { image }\end{array}$ & $-1 / 05$ & $-1 / 31$ & -18.05 & 113 & .0655 & $1 / 81$ & $\begin{array}{l}\text { Brand } \\
\text { image }\end{array}$ & 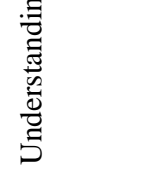 \\
\hline $\begin{array}{l}\text { Tourists' attitude toward Iran hasn't } \\
\text { led to strengthen tourism brand } \\
\text { identity and character. }\end{array}$ & $-1 / 16$ & $-1 / 41$ & -20.4 & 113 & .06314 & 1.71 & $\begin{array}{l}\text { Brand } \\
\text { identity and } \\
\text { character }\end{array}$ & \\
\hline $\begin{array}{l}\text { Tourists' attitudes toward Iran } \\
\text { hasn't led to Iran's ascendency in } \\
\text { compare to its competitors. }\end{array}$ & $-0 / 12$ & $-1 / 37$ & -19.90 & 113 & .06259 & 1.75 & $\begin{array}{l}\text { Brand } \\
\text { positioning }\end{array}$ & \\
\hline $\begin{array}{l}\text { Tourists' attitude toward Iran has } \\
\text { not led to maintenance of Iran's } \\
\text { brand image }\end{array}$ & $-1 / 26$ & $-1 / 48$ & -25.25 & 113 & .05448 & 1.62 & $\begin{array}{l}\text { Brand } \\
\text { image }\end{array}$ & 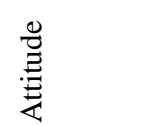 \\
\hline $\begin{array}{l}\text { Tourists' knowledge about Iran } \\
\text { hasn't led to strengthen tourism } \\
\text { brand identity and character. }\end{array}$ & $-1 / 14$ & $-1 / 37$ & -21.64 & 113 & .05822 & 1.74 & $\begin{array}{l}\text { Brand } \\
\text { identity and } \\
\text { character }\end{array}$ & \\
\hline $\begin{array}{l}\text { Tourists' knowledge about Iran } \\
\text { hasn't led to Iran's ascendency in } \\
\text { compare to its competitors. }\end{array}$ & $-0 / 95$ & $-1 / 24$ & -15.09 & 113 & .0727 & 1.9 & $\begin{array}{l}\text { Brand } \\
\text { positioning }\end{array}$ & $\frac{80}{8}$ \\
\hline $\begin{array}{l}\text { Knowledge of tourists has not led to } \\
\text { maintenance of Iran's brand image }\end{array}$ & $-1 / 25$ & $-1 / 47$ & -25.04 & 113 & .0545 & 1.63 & $\begin{array}{l}\text { Brand } \\
\text { image }\end{array}$ & $\begin{array}{l}\overline{3} \\
0 \\
\overline{1} \\
1\end{array}$ \\
\hline
\end{tabular}


In determining the extent of effect, according to Tables 4 and 5, the regression analysis has progressed only for two steps. In the step I tourists' understanding is entered the equation and its coefficient of correlation (R) with the dependent variable is 0.504 . In this stage the coefficient of determination is $\mathrm{R}^{2}=0.454$ and the coefficient of adjusted determination is $R_{A D}^{2}=0.241$. In the second step, when the second variable, the attitude of multiple correlation coefficient, is $\mathrm{R}=0.561$, coefficient of determination increases to ${ }^{2}=0.314$, adjusted determination coefficient increases to $\mathrm{R}_{\mathrm{AD}}^{2}=$ 0.710

In other words, based on the adjusted determination coefficient which is $71 \%$, changes of dependent variable are explained by two variables: brand perception and attitude to the brand.

Table 4: stepwise regression analysis

\begin{tabular}{llll}
\hline \multicolumn{2}{l}{ Variables Entered/Removed $^{\mathrm{a}}$} \\
\hline Model & $\begin{array}{l}\text { Variables } \\
\text { Entered }\end{array}$ & $\begin{array}{l}\text { Variables } \\
\text { Removed }\end{array}$ & Method \\
\hline 1 & Tourists' &. & $\begin{array}{l}\text { Stepwise (Criteria: Probability-of-F-to-enter }<= \\
\text {.050, Probability-of-F-to-remove }>=.100) .\end{array}$ \\
& understandin & & \\
\hline 2 & receptiveness &. & $\begin{array}{l}\text { Stepwise (Criteria: Probability-of-F-to-enter }<= \\
\text {.050, Probability-of-F-to-remove }>=.100) .\end{array}$
\end{tabular}

a. Dependent Variable: Iran tourism brand. 
Table 5- stepwise regression analysis: Model Summaryc

\begin{tabular}{|c|c|c|c|c|c|c|c|c|c|}
\hline \multirow[t]{2}{*}{ Model } & \multirow[t]{2}{*}{$\mathrm{R}$} & \multirow[t]{2}{*}{ R Square } & \multirow{2}{*}{$\begin{array}{l}\text { Adjusted R } \\
\text { Square }\end{array}$} & \multirow{2}{*}{$\begin{array}{l}\text { Std. Error of the } \\
\text { Estimate }\end{array}$} & \multicolumn{5}{|c|}{ Change Statistics } \\
\hline & & & & & $\begin{array}{l}\text { R Square } \\
\text { Change }\end{array}$ & F Change & df1 & $\mathrm{df} 2$ & $\begin{array}{l}\text { Sig. F } \\
\text { Change }\end{array}$ \\
\hline 1 & $.504^{\mathrm{a}}$ & .454 & .541 & 5.64279 & .454 & 19.721 & 1 & 112 & .000 \\
\hline 2 & $.561^{\mathrm{b}}$ & .614 & .710 & 5.45674 & .060 & 5.022 & 1 & 111 & .071 \\
\hline
\end{tabular}

a. Predictors: (Constant), dark

b. Predictors: (Constant), dark, negaresh

c. Dependent Variable: Iran tourism brand

F-value is significant at $99 \%(\mathrm{SIG}=0.000)$ that means regression is significant at the level of 99 percent.

Table 6. ANOVA was performed to determine the significance of regression: ANOVA ${ }^{a}$

\begin{tabular}{|c|c|c|c|c|c|c|}
\hline Model & & Sum of Squares & $\mathrm{df}$ & Mean Square & $\mathrm{F}$ & Sig. \\
\hline \multirow[t]{3}{*}{1} & Regression & 627.951 & 1 & 627.951 & 19.721 & $.000^{\mathrm{b}}$ \\
\hline & Residual & 1846.782 & 112 & 31.841 & & \\
\hline & Total & 2474.733 & 111 & & & \\
\hline \multirow[t]{3}{*}{2} & Regression & 777.498 & 2 & 388.749 & 13.056 & $.000^{\mathrm{c}}$ \\
\hline & Residual & 1697.235 & 111 & 29.776 & & \\
\hline & Total & 2474.733 & 113 & & & \\
\hline
\end{tabular}

a. Dependent Variable: Iran tourism brand

b. Predictors: (Constant), dark

c. Predictors: (Constant), dark, negaresh 
In Table 7, it is shown that "changing" variable is significant at the level of $99 \%$ and "attitude" variable is significant at the level of $95 \%$. It should be noted that error rate of other variables is greater than 0.05 , so they didn't enter the regression equation.

Table 7- coefficients of regression equation

\begin{tabular}{|c|c|c|c|c|c|c|}
\hline \multicolumn{7}{|c|}{ Coefficientsa } \\
\hline \multicolumn{2}{|c|}{ Model } & \multicolumn{2}{|c|}{ Unstandardized Coefficients } & \multirow{2}{*}{$\begin{array}{l}\text { Standardized Coefficients } \\
\text { Beta }\end{array}$} & \multirow[t]{2}{*}{$\mathrm{T}$} & \multirow[t]{2}{*}{ Sig. } \\
\hline & & $\mathrm{B}$ & Std. Error & & & \\
\hline \multirow[t]{2}{*}{1} & (Constant) & 18.412 & 5.086 & & 3.620 & .001 \\
\hline & Understanding & .518 & .117 & .504 & 4.441 & .000 \\
\hline \multirow[t]{3}{*}{2} & (Constant) & 13.948 & 5.307 & & 2.628 & .011 \\
\hline & understanding & .401 & .124 & .390 & 3.224 & .002 \\
\hline & attitude & .446 & .199 & .271 & 2.241 & .029 \\
\hline
\end{tabular}

a. Dependent Variable: Iran tourism brand. 
Based on the amount of $B$ in the table above, regression equation is written as follows:

$\mathrm{Y}=13.948+0.401($ dark $)+0.446($ negaresh $)$

But judgments about the role of each variable in explaining the dependent variable should be done by the standard values of beta, which help to compare variables and determine the role of them.

Although B value of attitude coefficient is more than understanding coefficient, role of understanding in explaining the dependent variable (tourism brand) is stronger than attitude's role, because based on obtained beta for "understanding", for a unit of change in standard deviation of "understanding variable", a change at the amount of 0.390 will occur in standard deviation of "tourism brand" while "attitude variable" makes a change at the amount of 0.271 in standard deviation of the dependent variable (brand). Also $\mathrm{T}$ in the above table shows that both variables, understanding and attitude, are significant and effective for estimation of value of Iran's tourism brand.

\section{DISCUSSION AND CONCLUSION}

The ultimate goal of this study is to evaluate the effect of Iran's tourism brand on attracting tourists to the country; although the only focus, at the present, is on tourism branding concepts. If we accept branding as a useful measure on the basis of logical thinking and the needs of the target market, a product or a destination brand must have functionality in order to advance the goals of marketing. In the Islamic Republic of Iran, we have no tourism brand. The results show that none of the independent variables have an effect on the dependent variable. Therefore, it can be argued that there is no tourism brand at the center of the model. In the current situation of country, branding has no apparent output and is not present in any dimension of the network connection. The results, relying on the opinion of tourism experts in the country, illustrate that despite having website, slogan, publications, videos, photos and few advertisements, Iran's tourism has no brand. According to available literature, the lack of tourism brand or its non-optimal performance can be consequent of two things:
If we imagine the brand core as a beating heart that pump a wave of brand identity into its four communication artery, and any developments in the brand experience originates from the central core, so the core of Iran's tourism brand (including the three elements of brand identity and character, brand positioning, brand image and originality) is not properly explained and its requirements, characteristics and consequences are not developed clearly.

No sufficient attention and investment have been specified in development of value and quality of tourists' understanding and knowledge and reformation of their attitude. The study results show that one reason of the improper function of brand communication network and not strengthening the central core by the independent variables, is the weakness in the explanation of the country's brand personality. When the brand properties are not real and there is no consensus among interested people, the achievement of such results is foreseeable. In fact, it is easy to understand the lack of clarity in brand personality by referring to Iran's official tourism sites and publications of tourism trustee organizations such as books, brochures, etc. Each named item, contain a set of features and attributes without any order or proposition; even each one has its own slogan for Iran's tourism and there is no integrated thought. No substantial image or presentations in line with destination values cannot be found in these sites and publications. Also, Visual identity, design, color and logo are not homogeneous and clear. Finally it is not clear for possible visitors that how really Iran is as a destination and what expectations they may generate before consumption. When the identity is not clear, positioning is not possible for the tourism brand, and distinguishing it and comparing it to the competitors will be very difficult and almost impossible. A brand without a clear identity cannot transcend its competitors. There is no promise or originality, if we don't know destination and the expectation we should generate. In fact, no distinct experience about the place authenticity has been promised to the tourists, so the destination doesn't have a clear program to act upon it or provide services and facilities. In explaining the second leading cause of Iran's tourism brand situation, we can say for creating a successful brand, we need to spend enough time and money. 
None of the relevant parties cannot reinforce Iran's brand, and this is a consequence of neglect and lack of investment in creating knowledge, understanding and correct attitude toward the destination. Relying on these findings, it is recommended that: a branding committee with executive powers and the specialized knowledge should be established by a trustee organization to determine the optimal model for branding and selecting logo and an efficient slogan, and pursue the required strategies to achieve the following set:

- The central core of Iran's tourism brand should be defined accurately, scientifically and upon reality, and based on an investigation of country's assets and properties.

- Investment and "attention to the sections relating to the creation of knowledge and attitude" should be accomplished, in line with the destination values and based on tourism brand.

- Media relations and international cooperation should be improved to strengthen and stabilize the tourism brand.

- Iran tourism target markets should be selected logically and based on brand.

- A strong network of interested pparties should be created in order to fulfill the brand's obligations.

- Service-oriented approach should be taken in order to improve the quality of the tourism experience

\section{REFERENCES}

Ahonen, M., Saraniemi, S. and Tähtinen, J. (2007). Does a country have an identity as a destination? An application of corporate identity into country level", Proceedings of Corporate Communications Institute Conference, Wroxton 1.-4.6.

Anholt, S. (2005). Three interlinking concepts: intellectual property, nation branding and economic development. WIPO International Seminar on Intellectual Property and Development, Geneva, May 2-3.

Baloglu, S. \& McCleary, K.W. (1999). A model of destination image formation. Annals of tourism research, 26, pp868-897.

Beerli, A. \& Martin, J.D. (2004). Tourist characteristics and the perceived image of tourist destinations: a quantitive analysis, a case study of Lanzarote, Spain. Tourism management.25, pp623-636.

Bornhorst. T., Ritchie. B., Sheehan. L. (2010). Determinants of tourism success for DMOs \& destinations: An empirical examination of stakeholders' perspectives. Tourism Management. Vol(31). pp 572-589.

Butler, R.W. McCartney, G., Bennett, M.(2008). Positive tourism image perceptions attract travellers - fact or fiction? The case of Beijing visitors to Macao Journal of Vacation Marketing 15 (2). pp179-193.

Cleverdon, R. and Fabricius, M. (2006). Destination positioning, Branding and image Management. W. T. O Manila. 20-22 march. [online] Available from: http://www.destinationpositioningimage. Wtomanila2022/032006_pdf. Accessed in16/05/2012.

ETC / UNWTO Handbook on Tourism Destination Branding. (2010) . [online] Available from: http://www.etccorporate.org/modules.php?name $=$ Content $\&$ pa $=$ showpage $\&$ pid $=239$.

Barzani, Helia (1392). Tourism brand of Pathology, Research Bazaryaby.63-80: 8, new.

Balvyy, H. (1391). Analysis of strengths, weaknesses, opportunities and threats of foreign tourists Isfahan province using AHP phase of planning and tourism development, first year, No. 13-34: 1.

Soleimani, M. (1391). Measuring tourist satisfaction in Gorgan, Journal Tourism Management Studies, Vol. 7, No. 20: 0.31 to 48 .

Ghasemi-V. (1392). Using structural equation modeling in social studies Amos Graphics, Tehran: sociologists.

Respectable V. (1392). Social impact assessment - cultural tourism, urban lifestyle of the people Babolsar, planning and development of tourism, the second year, No. 126-147: 7.

Hezarjarib J. (1391). Sociological study of factors affecting the development of tourism in the approach to attract foreign tourists, geography and environmental planning, No. 133-146: 3.

Yazdi, H. (1389). Factors affecting brand equity in Mqsdgrdshgry Yazd Tourism Studies, No. 113-137, 13

${ }^{\mathrm{i}}$ In the ruins of Persepolis which was the capital of the Achaemenid two stone statues of Homa have been found. This suggests that Homa has been bird of welfare in ancient Iran. Homa (Homai) has had a prominent place in literature. In the poems of many poets, homa is mentined as the bird of happiness and prosperity. In Persian literature it is considered as a symbol of glory and luck. 